\title{
UNIVERSITAS ISLAM NEGERI DAN RENAISANS BARU PENDIDIKAN ISLAM DI INDONESIA
}

\author{
Kutsiyyah \\ Dosen IAIN Madura Pamekasan
}

\begin{abstract}
Dikotomi ilmu yang menjadi warisan dalam bangsa ini mengakibatkan kemandegan dalam peradaban Islam. Salah satunya dalam pendidikan Islam yang telah kalah jauh dari kemajuan ilmu-ilmu Eropa sejak berabad-abad lamanya. Munculnya inovasi-inovasi baru dalam sistem pendidikan Islam, yakni perpaduan ilmu umum \& agama akan menjadi arah baru bagi bangkitnya pendidikan Islam di Indonesia. Misalnya pemaduan pendidikan pesantren dan kampus sebagaimana banyak disampaikan oleh pakar pendidikan Islam. Model ini, penulis melihat bisa saling melengkapi dalam memanfaatkan kelebihan dan menutupi kekurangan masing-masing untuk diterapkan pada pendidikan masa kini. Maka dengan perubahan status STAIN/IAIN menjadi UIN memberikan angin segar bagi tumbuhnya pendidikan Islam di Indonesia, yang utuh, holistik, integratif dan responsif terhadap era modern ini. Pengkotak-kotakan ilmu akan teratasi dengan konsep integrasi keilmuan yang ditawarkan oleh masing-masing UIN.
\end{abstract}

Keywords : UIN, Renaisans, Pendidikan Islam.

\section{Pendahuluan}

Pendidikan memiliki peranan yang sangat penting, bahkan paling penting dalam mengembangkan dan memajukan peradaban. Semakin banyak pengetahuan dan ilmu yang dimiliki, maka semakin besar peluang untuk maju. Dalam sejarah Islam hal ini telah dibuktikan pada masa Abbasiyah. Banyak kajian-kajian keilmuan yang dilakukan di majelis-majelis, hingga Islam sampai pada masa keemasannya. 
Kutsiyyah

Pendidikan merupakan pintu masuk suatu peradaban. Dari sini, seseorang akan mendapat pencerahan dan mulai mencari jati diri yang lebih baik. Dalam hal ini tentu pendidikan juga harus memiliki sistem yang baik agar cita-cita atau esensi dari pendidikan tersebut bisa tercapai.

Selama ini, dalam Islam khususnya di Indonesia, pandangan dikotomi ilmu masih terleihat kental bahkan dalam kelembagaan pemerintahan pun sangat jelas adanya dikotomi ilmu, seperti kementerian pendidikan dan kebudayaan yang menaungi institusi/sekolah umum dan kementrian agama menaungi institusi/sekolah agama.

Ada paradigma keilmuan yang perlu diluruskan dalam hal ini untuk mencapai kesempurnaan dalam mengamalkan ajaran Islam yang rahmatan lil 'alamin. Oleh karena itu, banyak tokoh Islam yang kemudian sadar bahwa dalam Islam tidak ada dikotomi ilmu, bahka dalam era keemasan peradaban Islam telah membuktikan pentingya integrasi ilmu untuk mencapai kemajuan.

Semangat integrasi ini kemudian tampak dengan adanya beberapa perubahan status kelembagaan Sekolah Tinggi Islam/Institute Agama Islam Negeri (IAIN) menjadi Universitas Islam Negeri (UIN). Perubahan ini mencerminkan adanya cita-cita yang lebih besar untuk pendidikan Islam.

Untuk itu, dalam tulisan ini akan dikaji bagaimana UIN mengawal serta mengembangkan pendidikan Islam kedepannya. Dengan kata lain, UIN diharapkan bisa menjadi pelopor dalam kebangkitan pendidikan Islam khususnya di Indonesia. Maka, di tangan kampus-kampus Islam inilah, kejayaan Islam diharapkan kembali berkibar dan menjemput renaisans.

\section{Diskursus Perubahan IAIN/STAIN ke UIN}

Beralihnya status perguruan tinggi Islam menjadi UIN, merupakan gebrakan baru dalam dunia pendidikan Islam di Indonesia. Fenomena ini juga cerminan dari reorientaasi pendidikan Islam. Predikat 'universitas' yang identik dengan kampus-kampus umum, memberi wajah baru bagi lembaga pendidikan Islam. Ada gambaran bahwa lembaga Islam ini mulai membuka diri terhadap dunia luar dan kemajuan ilmu pengetahuan.

Sebagaimana yang ditulis Marwan Saridjo, di antara alasan beberapa pimpinan UIN sekarang untuk memperjuangkan IAIN menjadi UIN adalah: pertama, dengan berubahnya status Institut menjadi Universitas, mereka dapat mengembangkan program studi dan fakultas non-agama atau fakultas umum yang memungkinkan IAIN/UIN memperoleh akses yang lebih luas dalam mencari 
lowongan kerja. Kedua, ini yang sangat penting, yakni untuk mengintegrasikan pengetahuan agama dan pengetahuan umum yang selama ini bersifat dikotomik dengan implikasinya yang tidak diinginkan. ${ }^{1}$

Dari alasan tersebut, maka yang menjadi alasan mendasar dari transformasi IAIN menjadi UIN adalah integrasi ilmu. Dikotomi ilmu yang selama ini melekat kuat pada umat Islam menjadikan Islam kurang berkembang dan jauh tertinggal dari ilmu-ilmu umum yang telah berkembang pesat. Keyakinan bahwa AL Qur'an dan Hadits adalah sumber ilmu tidak dapat diaplikasan secara nyata. Hal ini bukan karena tidak terdapat dalam Al Quran dan Hadits, melainkan pola pikir umat Islam yang hanya memandang bahwa agama adalah persoalanpersoalan yang mengkaji halal haram, akhlak dan ibadah-ibadah lainnya yang bersifat formalitas dan praktis.

Dalam tulisannya, Amin Abdullah menjelaskan bahwa keputusan menuju Universitas Islam Negeri ini diambil, yakni untuk memberi kesempatan kepada IAIN Jakarta dalam menyiapkan transformasi kelembagaannya. Ada kesan bahwa perhatian IAIN lebih banyak terfokus pada pembinaan masyarakat melalui fungi dakwaknya daripada pengembangan ilmu pengetahuan. Alasan lain adalah bahwa kurikulum IAIN belum mampu merespon perkembangan iptek dan perubahan di masyarakat yang semakin cepat dan mengglobal. Kurikulum IAIN kurang bersentuhan dan belum dilakukan pendekatan ulang secara intens dengan ilmuilmu umum. Dengan kata lain kurikulum IAIN masih bernuansa dikototomis antara ilmu umum dan agama. ${ }^{2}$ Maka cukup jelas, perubahan status menjadi UIN adalah guna membangun kembali orientasi pendidikan Islam yang lebih holistic, integratif dan responsif.

Terlepas dari akar masalah pola pikir dikotomik keilmuan dalam pendidikan Islam, adalah bahwa ilmu adalah sesuatu yang niscaya dan urgen. Semua kalangan bisa mempelajarinya, jenis apapun ilmu tersebut. Hanya kemudian, ilmu yang didapat itulah yang akan mentukan baik tidaknya dalam pengaplikasiannya. Dengan kata lain, suatu ilmu menjadi baik atau sebaliknya ketika dalam tataran aplikasi.

\footnotetext{
${ }^{1}$ Marwan Saridjo, Pendidikan Islam Dari Masa Ke Masa; TInjauan Kebijakan Publik Terhadap Pendidikan Islam di Indonesia (Bogor: Yayasan Ngali dan al Manar Press, 2011) hlm. 199

${ }^{2}$ Ibid. hlm. 53
}

Kariman, Volume 07, Nomor 01, Juni 2019| 45 
Kutsiyyah

\section{UIN: Integrasi Keilmuan Pendidikan Islam}

Dikotomi keilmuan yang selama ini melekat pada masyarakat, khususnya masyarakat akademik yang semestinya bisa mengembangkan keilmuan lebih maju, dalam kondisi riilnya masih belum bisa mengembalikan kejayaan Islam seperti dahulu yang menjadi pusat peradaban dunia. Pendidikan Islam malah semakin terlihat kolot dari kemajuan dunia luar yang semakin canggih.

Dikotomi ilmu ini memberikan dampak kurang baik bagi pengembangan keilmuan Islam. Yang ada hanyalah kemandegan dalam memaknai wahyu dan hanya pada wilayah teosentris. Berikut beberapa permasalahan yang penulis kutip yang menyelimuti pendidikan Islam sebagai akibat dari munculnya dikotomi sistem pendidikan: ${ }^{3}$

a. Munculnya ambivalensi orientasi pendidikan Islam.

b. Kesenjangan antar sistem dalam pendidikan Islam dan ajaran Islam.

c. Disintegrasi sistem pendidikan Islam.

d. Inferioritas para pengasuh lembaga pendidikan Islam.

Sebagaimana dijelaskan di muka, bahwa peralihan status IAIN menjadi UIN bukanlah perubahan yang bersifat fisik saja (kelembagaan) melainkan juga mengemban amanah besar pendidikan Islam untuk bisa menyentuh segala aspek kehidupan mayarakat dan mampu bersaing di kancah internasional. Itulah harapan besarnya. Maka dari itu, transformasi kelembagaan ini juga harus diiringi dengan peningkatan kualitas para civitas akademika.

Beberapa UIN yang terdapat di Indonesia telah memiliki ciri khas masingmasing dalam integrasi dan mengembangkan pendidikan Islam. Untuk mengatasi hal tersebut di atas tampak bahwa UIN Jakarta, Yogyakarta, dan Malang telah berupaya melakukan integrasi keilmuan dengan cara dan pola yang menggambarkan kekhasan paradigma yang mewakili pergulatan pemikiran di dalamnya. Hal ini tentunya bagian dari upaya mengakhiri dikotomi keilmuan yang tidak selaras dengan misi Islam sebagai agama yang menebarkan kehidupan Rahmatan lil 'alamin.

1. UIN Syarif Hidayatullah Jakarta

Sebagaimana diketahui bahwa dalam sejarahnya, UIN Syarif Hidayatullah Jakarta merupakan kampus Islam pertama yang menyandang status UIN. Sejak itu, kampus ini terus membenahi diri dalam mengembangkan akdemiknya.

\footnotetext{
${ }^{3}$ M. Zainuddin, Paradigma PEndidikan Terpadu, MEnyiapkan Generasi Ulul ALbab (Malang: UIN-Malang Press, 2008) hlm. 30
}

46 | Kariman, Volume 07, Nomor 01, Juni 2019 
UIN Syarif Hidayatullah tidak memiliki simbol khusus yang mencirikan integrasi keilmuan yang dikembangkan disana. Namun demikian, pada prinsipnya kampus ini sudah melaksanakan integrasi ilmu.

Sebagaimna ditulis oleh Abubin Nata dalam sebuah artikelnya, bahwa pembicaraan mengenai pengembangan akademik di UIN Jakarta tidk lepas dari latar belakang berubahnya status IAIN ke UIN. Selain untuk memberi peluang yang besar kepada lulusan UIN Syarif HIdayatullah Jakarta untuk berkiprah dalam masyakat juga untuk menghilangkan paradigma dikotomi ilmu yang diwariskan abad pertengahan. ${ }^{4}$

Menurut Abudin Nata, definisi konsep integrasi ilmu dari Amin Abdullah yang mengambil metafora jaring laba-laba dan dari Imam Suprayogo yang mengambil metafora "pohon ilmu" nampak lebih istematis,jelas dan tuntas dan orisinal. Namun konsep ini berhenti pada tahap konsep dan wacana dan belum diturunkan pada dataran pengembangan fakultas, program studi, kurikulum, silabus dan proses belajar mengajar evauasi dan lainnya. Praktek pengembangan akademik dan berbagai aspeknya yang terdapat pada UIN Sunan Kalijaga Yogyakarta dan UIN Maulana Malik Ibrahim Malang masih belum tersentuh oleh konsep "jaring laba-laba" dan "pohon ilmu" tersebut. ${ }^{5}$ Oleh karena itu, di UIN Syarif Hidayatullah lebih memilih langkah-langkah kongkrit yang langsung diaplikasikan dalam pengembangan akademiknya.

Pola dan strategi pengembangan akademik di UIN Syarif Hidayatullah Jakarta tidak mengambil bentuk Islamisasi ilmu dengan berbagai macam metodenya. Pengembangan akademik di UIN Syarif Hidayatullah Jakarta pada prinsipnya menggunakan konsep integrasi ilmu yang dilakukan melalui tahapan sebagai berikut. Pengembangan akademik di UIN syahid Jakarta pada prinsipnya menggunakan konsep integrasi ilmu yang dilakukan melalui tahapan berikut. ${ }^{6}$

a. Pendekatan IAIN With Wider Mandate

Pendekatan IAIN with Wider Mandate (IAIN dengan mandat yang lebih diperluas) ini dilakukan sebagai tahap persiapan pengembangan akademik pada saat IAIN sudah menjadi UIN. Konsep Wider Mandate ini

\footnotetext{
${ }^{4}$ Abudin Nata, dalam artikel Pengembangan Akademik di UIN Syarif Hidayatullah Jakarta, fdi.uinjkt.ac.id/in, diakses, 28 Juni 2014

${ }^{5}$ Ibid.

${ }^{6}$ Ibid.
}

Kariman, Volume 07, Nomor 01, Juni 2019| 47 
Kutsiyyah

sesungguhnya merupakan pengembangan dari adanya sejumlah program studi umum yang terdapat pada Fakultas Ilmu Tarbiyah dan Keguruan, serta lainnya.

b. Penyempurnaan visi, misi, tujuan, dan motto

c. Mengintegrasikan ilmu yang berbasis ayat Qur'aniyah dan ayat Kauniyah

d. Penempatan posisi ilmu agama dan ilmu umum secara sejajar

e. Mendorong ilmu agama dan ilmu umum agar tumbuh berdampingan

f. Penggunaan ilmu umum sebagai pendekatan dalam studi ilmu agama (kurikulum agama yang memuat ilmu umum)

g. Penggunaan ilmu agama sebagai jiwa ilmu umum

h. Pembukaan program double degree (gelar ganda)

Pola dan strategi pengembangan akademik pada UIN Syarif Hidayatullah Jakarta juga dilakukan dengan membuka program ganda (double degree). Cara ini ditempuh selain, agar terjadi proses integrasi ilmu, juga agar memberikan peluang yang lebih besar kepada lulusan UIN Syarif Hidayatullah Jakarta. Selain dapat bekerja pada bidang keagamaan, lulusan tersebut juga dapat bekerja pada bidang non-keagamaan secara lebih luas sambil tetap membawa misi Islam sebagai rahmat bagi seluruh alam.

Demikian penjelasan singkat bagaimana integrasi di UIN Syarif Hidayatullah Jakarta. Meskipun tidak mengekspresikan pola integrasinya dalam bentuk visualisasi/simbolisasi tertentu, menawarkan bentuk integralisme yang lebih praktis pragmatis. ${ }^{7}$ UIN yang pertama kali ada di Indonesia ini, sudah menerapkan integrasi keilmuannya langsung pada tataran praktis dan aplikatif meski tanpa adanya simbol sebagaimana yang lainnya.

2. UIN Sunan Kalijaga Yogyakarta

Di sini, penulis berikan poin pokok integrasi ilmu yang terdapat di UIN Sunan Kalijaga Yogyakarta yang disimbolkan dengan "jaring laba-laba." Dalam hal ini UIN Sunan Kalijaga menawarkan bangun keilmuan model jaring-jaring keilmuan. Symbol ini menunjukkan integrasi keilmuan teoantroposentrik-integralistik.

Apa yang dicanangkan oleh M. Amin Abdullah dalam bukunya Islamic Studies merupakan program dari penyatuan kembali antara ilmu

\footnotetext{
${ }^{7}$ http://academia.edu/, diakses 8 Mei 2014.
} 
pengetahuan dengan ajaran agama. Seperti yang dikutip dalam bukunya, bahwa "agama mengklaim sebagai sumber kebenaran, etika, hukum, kebijaksanaan, dan sedikit pengetahuan. Agama tidak pernah menjadikan wahyu tuhan sebagai satu-satunya sumber pengetahuan. Menurut pandangan ini, sumber pengetahuan ada dua macam, yaitu pengetahuan yang berasal dari Tuhan dan pengetahuan yang berasal dari manusia. Perpaduan antara keduanya disebut teoantroposentris". ${ }^{8}$

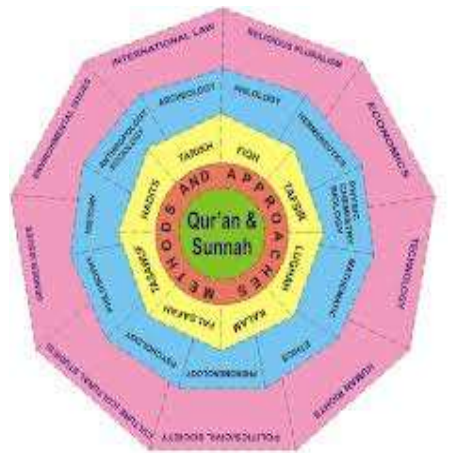

Dari gambar di atas dapat dilihat bagaimana model integrasi yang dibangun di UIN Sunan Kalijaga Yogyakarta. Masyarakat akdemik dibangun kesadaran epistemologinya untuk bisa mensejajarkann ilmu Islam dengan ilmu pengetahuan tanpa ada sekat. Keduaya harus berjalan bersama tanpa ada pertentangan satu sama lain. Sebagaimana juga ditulis oleh Amin Abdullah bahwa ini merupakan keilmuan yang integratif-interkoneksif yakni ilmu agama maupun umum adalah saling berkaitan.

3. UIN Maulana Malik Ibrahim Malang

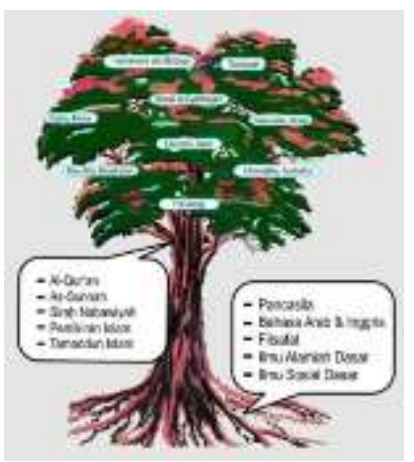

Lain di UIN Sunan Kalijaga yang melambangkan jaring laba-laba dalam visualisasi integrasi keilmuan, maka lain pula yang digunakan di UIN Maulana Malik Ibrahim Malang. Di kampus yang mengganti satusnya dari STAIN langsung menjadi UIN ini menjadikan pohon sebagai lambang integrasi keilmuan yang dikembangkan di sana.

Sebagaimana terlihat pada gambar di samping, pohon ilmu tersebut merupakan buah dari pemikiran

\footnotetext{
${ }^{8}$ M. Amin Abdullah, Islamic Studies di Perguruan Tinggi Pendekatan Integratif-Interkonektif (Yogjakarta: Pustaka Pelajar, 2012)
}

Kariman, Volume 07, Nomor 01, Juni 2019| 49 


\section{Kutsiyyah}

rektor yang menjabat saat itu, Imam Suprayogo. Pohon merupakan tamsil yang cocok menurutnya untuk menggambarkan lebih jelas hubungan agama dan ilmu.

Lebih jauh lagi beliau menjelaskan bahwa ibarat sebuah pohon, maka tentu ia memiliki akar, batang, daun, dahan, ranting dan buah. Pohon yang memiliki akar yang kuat menghujam ke bumi tidak akan mudah terombangambing bahkan tidak roboh diterjang angin sekencang apapun. Pohon yang kuat akan melahirkan buah yang segar.

Dalam perspektif kurikulum, akar yang menghujam ke bumi digunakan sebagai tamsil sejumlah ilmu atau keterampilan yang harus dikuasai oleh mahasiswa yang belajar di perguruan tinggi Islam. Beberapa ilmu dan keterampilan yang dimaksud adalah (1) bahasa Asing (Arab dan Inggris), (2) Filsafat, (3) Ilmu alam, dan (4) ilmu sosial. Bahasa Arab dianggap penting agar mahasiswa mampu memahami Al Qur'an, hadits Nabi, maupun kitab-kitab yang berisi ajaran Islam dalam bahasa Arab lainnya. Ilmu alam dan ilmu sosial juga dipandang penting dikuasai dan digunakan sebagai alat bantu untuk memahami ajaran Islam. Sebab, Al Qur'an maupun Hadits banyak memberikan gambaran atau sinyal tentang dunia, alam semesta, maupun sosial. ${ }^{9}$

Selanjutnya, apabila empat bidang ilmu tersebut dapat dikuasai secara baik oleh mahasiswa, maka yang bersagkutan sangat dimungkinkan bisa memahami ajaran Islam, yakni (1) AL Qur'an, (2) As-Sunnah, (3) Sirah Nabawiyah, (4) pemikiran Islam dan (5) masyarakat Islam. Beberapa ilmu ini dapat digambarkan sebagai sebuah batang dari poho yang kokoh dan rindang. Batang dan akar tersebut menggambarkan ilmu agama, yang menurut AL Ghazali fardu 'ain menuntutnya. Demikian juga, hal itu harus dikuasai dan dipelajari oleh seluruh mahasiswa universitas Islam, apapun jurusannya. Sedangkan dahan, ranting dan daun menggambarkan jenis fakkultas/jurusan yang dipilih. Oleh karena itu, mahasiswa akan mengambil secara berbeda. Hal ini jika memimjam istilah Al Ghazali adalah yang dikategorikan dengan fardu kifayah. ${ }^{10}$

Adapun buah yang segar menggambarkan iman dan amal shalih. Buah segar tersebut hanya akan muncul dari pohon yang memiliki akar yang kuat yang menghujam ke bumi, batang, dahan, dan daun yang lebat secara utuh. Buah yang segar tidak akan muncul dari akar dan pohon yang tidak memiliki dahan, ranting dan daun yang lebat. Demikian pula buah yang segar tidak akan muncul dari

\footnotetext{
${ }^{9}$ Imam Suprayogo, Pendidikan Berparadigma Al Qur'an; Pergulatan Membangun Tradisi dan Aksi Pendidikan Islalm (Malang: UIN Malang Press, 2004), hlm. 50

${ }^{10}$ Ibid. 51
}

50 | Kariman, Volume 07, Nomor 01, Juni 2019 
pohon yang hanya memiliki dahan, ranting da daun tanpa batang dan akar yang kokoh. Sebagai pohon yang diharapkan melahirkan buah yang segar, harus secara sempurna terdiri dari akar, batang, dahan, ranting dan daun yang sehat dan segar pula. Tanpa itu semua mustahil pohon tersebut melahirkan buah. Demikian pula ilmu yang tidak utuh, yang hanya sepotong-sepotong akan bagaikan sebuah pohon yang tidak sempurna. Ia tidak akan melahirkan buah yang diharapkan yakni iman dan amal shalih. ${ }^{11}$ Inilah penjelasan rinci tentang pohon ilmu yang menjadi cirri khas integrasi keilmuan yang ada di UIN Maulana Malik Ibrahim Malang.

Dalam berbagai seminar pendidikan Islam, tidak jarang disampaikan oleh Imam Suprayogo dengan penuh keyakinan bahwa UIN Malang dalam 10 tahun ke depan dapat menjadi kampus sebesar Al Azhar di Mesir, atau bisa menjadi Universitas Islam terbesar di dunia.

Cita-cita yang ditargetkan kampus-kampus UIN di Indonesia memang sangat besar. Maka dengan adanya integrasi ini, setiap kampus bisa membuka fakultas umum yang nantinya bernafaskan Islam. Dengan demikian diharapkan UIN bisa membawa pendidikan Islam pada peradaban yang maju.

Seiiring perkembangan zaman, perubahan-perubahan dalam masyarakat muslim Indonesia yang terjadi tidak hanya pada tingkat intelektual atau pemikiran, tetapi juga pada tingkat kelembagaan ssebagaiman dijelaskan. Perubahan pada kedua aspek ini berkaitan erat satu sama lain, dan karena itu, perubahan pada tingkat kelembagaan Islam di kawasan ini pada dasarnya sekaligus merupakan pengejewantahan atau aktualisasi dari perubahan dan perkembangan yang terjadi pada tingkat pemikiran. ${ }^{12}$

Dengan kata lain, yang terjadi dalam proses pengembangan IAIN ke UIN menunjukkan adanya proses dinamika pemikiran Islam di Indonesia yang juga tidak pernah terkelupas dari perkembangan sosial politik yang mendasarinya. ${ }^{13} \mathrm{Apa}$ yang dicapai dan berkembang saat ini dalam pendidikan Islam merupakan hasil dari perjalanan panjang berbagai aspek yang mewarnai sejarah Islam khususnya yang ada di Indonesia.

Oleh sebab itu, integrasi keilmuan ini diharapkan bisa membawa pada pemahaman yang lebih universal. Ilmu-ilmu dikaji dan digali dengan penuh semangat bahwa ia juga merupakan perintah Tuhan yang tertulis dalam kitabNya. Sebab sebagaimana diketahui, banyak sekali ayat yang mengajak umat Islam

\footnotetext{
${ }^{11}$ Ibid.

${ }^{12}$ Azyumardi Azra, http://icas.ac.id/dinamika-islam-menuju-renaisans-indonesia, diakses 8 Mei 2014.

13 Juhaya S. Praja, Filsafat dan Metodologi Ilmu dalam Islam (Jakarta: Teraju, 2002) hlm. 135.
} 
Kutsiyyah

untuk berpikir tentang ciptaan-Nya dan mencermati apa yang terjadi di langit dan di bumi.

\section{Masa Depan Perguruan Tinggi Islam}

Akankah UIN bisa menjadi pelopor kebangkitan pendidikan Islam di Indonesia? Bagaimana masa depan Perguruan Tinggi Islam? Dari penjelasan di atas, dari berubahnya status STAIN, IAIN menjadi UIN dari segi kelembagaan dan adanya semangat integrasi ilmu yang diprogramkan setiap kampus, maka tidak menutup kekmungkinan jika semangat dan motivasi ini tetap ada akan bisa membuka kembali kejayaan pendidikan Islam. Dengan adanya transformasi kelembagaan dari IAIN menjadi UIN, kesan dikotomi yang dianggap sebagai salah satu kemandegan Islam akan dapat dihapus dengan adanya paradigm berpikir masyarakkat akademik yang lebih terbuka dan integratif.

Dalam tulisan ini, dirasa sangat penting juga mengulas sedikit tentang pemaduan pendidikan pesantren dan kampus sebagaimana banyak disampaikan oleh pakar pendidikan Islam. Model ini penulis rasa bisa saling melengkapi dalam memanfaatkan kelebihan dan menutupi kekurangan masing-masing untuk diterapkan pada pendidikan masa kini.

Menurut Malik Fadjar, masalah mendasar yang muncul dalam pendidikan Islam adalah bagaimana orientasi kembaga-lembaga pendidikan Islam yang ada sekarang ini, baik yang berbentuk pondok pesantren, madrasah, maupun sekolah dan perguruan tinggi. Menurutnya, harus diakui bahwa apa yang selama ini menjadi cita-cita ideal lembaga pendidikan Islam maih angat abstrak umum. Akibatnya yang muncul (operasionalnya) juga kurang mencerminkan kejelasan atau mungkin Nampak 'semu'. ${ }^{14}$ Menurut hemat penulis, hal ini yakni cita-cita yang melangit dan tidak jelas dalam tataran operasionalnya merupakan ceriminan dari masih minimnya konsep pendidikan Islam yang lebih bersifat responsif.

Sebagaimana ditulis oleh Ahmad Barizi bahwa sistem pendidikan asrama ini merupakan sesuatu yang urgen diterapkan mengingat mahasiswa adalah subsistem dari kehidupan kampus serta aset yang sangat berharga bagi kelangsungan nilai dan sistem pendidikan perguruan tinggi di masa depan. Mahasiswa adalah pilar penyanggah perjuangan generasi ke generasi dimana peran sosialnya dalam sejarah dituntut untuk bisa mencerminkan yang baik dalam sisi intelektual,

\footnotetext{
${ }^{14}$ A. Malik Fadjar, Pergumulan Pemikiran Pendidikan Tinggi Islam (Malang: UMMPress, 2009) hlm. 58
} 
spiritual dan bahkan emosionalnya. ${ }^{15}$ Dengan sistem asrama ini bisa menanamkan dan menjaga nilai-nilai agama. Dengan demikian mahasiswa tidak akan mudah terjerumus dalam pergaulan bebas dan terkikis oleh arus modernitas yang banyak menawarkan sekularisme.

Maka pesan Ali bin Abi Thalib r.a bisa menjadi tolak ukur dalam hal ini; "Didiklah anak-anak kalian dengan hal-hal yang tidak seperti yang telah kalian pelajari/ajarkan. Sesungguhnya mereka itu diciptakan dalam zaman yang berlainan dengan zaman kalian diciptakan". Pesan di atas juga menyampaikan bahwa seharusnya pendidikan berpikir dan melihat jauh ke depan dengan menyiapakan generasi yang siap dan mampu menjalani kehidupannya dengan baik. Selain manfaat di atas, dengan adanya sistem asrama juga bisa membantu mengembangkan keilmuan secara bersama dengan mahasiswa lainnya. Secara tidak langsung diskusi, kegiatan dan kajian-kajian keilmuan akan bisa terbentuk dengan sendirinya karena tempat yang dihuni bersama memungkinkan untuk melakukan hal-hal tersebut.

Dalam sebuah kesempatan kuliah umum Filsafat Islam yang penulis ikuti, Amin Abdullah yang saat itu sebagai dosen tamu menyampaikan bahwa pendidikan pesantren memiliki kajian kitab-kitab Islam yang bagus. Hanya saja mereka lebih menekankan pada aspek bayani dan irfani dan kurang dalam mengembangkan sisi burhani. Inilah yang menjadi kekurangan pesantren sehingga yang terjadi adalah ketakutan ketika dihadapkan pada pemikiran yang sedikit keluar dari 'garis Islam' dalam pandangan mereka.

Dalam filsafat Islam terdapat tiga cabang epistimologi yang dapat dijadikan kerangka anlisis dalam pemikiran Islam, yakni apa yang disebut oleh Mohammad Abid al Jabiri dengan epistemology bayani, irfani dan burhani. Menurut Al JAbiri, corak epistemology bayani didukung oleh pola pikir fikih dan kalam. Dalam tradisi keilmuan agama islam di IAIN dan STAIN, begitu juga pengajaran agama Islam di perguruan tinggi umum dan lebih-lebih di pesantrenpesantren, corak pemikiran bayani sangatlah mendominasi dan bersifat hegemonic dan sulit berdialog dengan dengan tradisi epistemologi irfani dan bayani. ${ }^{16}$

Kelemahan yang mencolok dari tradisi nalar pistemologi bayani atau tradisi berpikir tekstual keagamaan dalam berhadapan dengan komunitas lain

\footnotetext{
${ }^{15}$ Ahmad Barizi, Pendidikan Intgratif; Akar Tradisi dan Integrasi Pendidikan Islam (Malang: UIN Maliki Press, 2011) hlm. 92

${ }^{16} \mathrm{M}$. Amin Abdullah, Islamic Studies di Pergruruan Tinggi; pendekatan Integratif-interkonektif(Yogyakarta: Pustaka Pelajar, 2010) hlm. 202
}

Kariman, Volume 07, Nomor 01, Juni 2019| 53 


\section{Kutsiyyah}

agama, corak argument model ini biasanya mengambil sikap mental yang bersifat dogmatic, defensive, apologis dan polemis dengan semboyan kurang lebih "right or wrong my country". Sedangkan pola epitemologi irfaani lebih bersumber pada intuisi dan bukannya teks. Karena itu, kajian-kajian abru dan serius tentang kerangka berpikir irfani perlu terus menerus dikaji dan digali ulang agar dapat dipahami secra praktis fungsional. Selanjutnya yang terakhir yakni epistemology burhany. Ibnu Rusyd sebagai tokoh filosof muslim klasik telah menyebut-nyebut jenis epistemology ini. Namun corak hegemoni bayani menjadikan burhani dan irfani tersingkir dari panggung sejarah pemikiran keislaman. ${ }^{17}$ Bayani, irfani dan burhani merupakan warisan khazanah keilmuan Islam yang harus dijaga dan dikembangkan.

Jika sumber keilmuan dari corak epistemology bayani adalah teks, sedang irfani adalah direct experience, maka epistemologi burhani adalah bersumber pada realitas atau al waqi' baik realitas alam, sosial, humanitas maupun keagamaan. Ilmu-ilmu yang muncul dari tradisi burhani ini disebut sebagai al ilmu al husuli, yakni ilmu yang dikonsep, disusun dan disistematikan lewat premis-premis logika atau al mantiq, dan bukannya lewat otoritas teks atau salaf dan bukan pula lewat otoritas intuisi. ${ }^{18}$

Tiga dimensi epistemology Islam inilah yang harus diterapkan dalam pengembangan pendidikan Islam, di perguruan tinggi khususnya. Terutama dalam aspek burhani, maka perlu lebih lagi dioptimalkan dan harus ada di kampus agar paradigm berpikir mahasiswa lebih aktif dalam merespon fenomena kehidupan. Adapun burhani dalam lingkungan pesantren sangat jarang dilakukan.

Perpaduan sistem pesantren atau ma'had dengan tradisi kampus akan membentuk pendidikan Islam yang lebih baik untuk menyongsong peradaban Islam yang lebih maju. Sebagaimana sering juga disampaikan baik dalam tulisan maupun seminar oleh Prof. Imam Suprayogo bahwa "jadilah ulama yang intelek atau intelek yang ulama".

Masa depan UIN bisa dilihat dari model pendidikannya saat ini. UIN setelah mendapatkan statusnya yang baru sebagai cermin adanya perubahan konsep pendidikan Islam integratif, maka adalah menjadi masyarakat kampus tersebut untuk membangun kualitasnya. Di antara ciri pendidikan yang berkualitas adalah pada penggunaan advance infrastructrure, yaitu dengan tenaga pengajar dan

\footnotetext{
${ }^{17}$ Ibid. 212

${ }^{18}$ Ibid. 213
}

54 | Kariman, Volume 07, Nomor 01, Juni 2019 
proses belajar yang berkualitas. Sehingga pendidikan mampu memfasilitasi peserta didik/mahasiswa untuk mencapai high level thingking. high level thingking yakni kemampuan berpikir tingkat tinggi yang kompleks dan rumit, yaitu kemampuan penerapan, analisis, sintesis, dan evaluasi. ${ }^{19}$

Imam Suprayogo dalam memandang masa depan UIN, khususnya UIN MAulana Malik Ibrahim Malang, ia dengan tegas dan yakin menjawab bahwa kampus ini bisa menjadi sebagai pengubah. Mengapa? (1) keyakinannya sebagai seorang Islam, (2) posisinya sebagai seorang praktisi (3) dan predikat sebagai seorang ilmuan. ${ }^{20}$ Jawaban ini menunjukkan adanya sikap optimis. Sebab jika semua alat/kebutuhan untuk maju sudah tersedia, maka hahnya tinggal individunya untuk menjalankannya. Akan berbeda lagi jika sikap pesimis dan kurang percaya diri tetap ada pada pendidikan Islam. Maka yang terjadi adalah ketakutan dalam mengambil langkah yang besar untuk tujuan yang besar pula.

Bidang apa yang harus digarap? Tentu saja fakultas-fakultas yang sudah ada di UIN dan konsep yang sudah matang yang perlu diolah dan dilaksanakan. Ini adalah kekuatan besar yang dimiliki untuk maju. Lalu kenapa terkadang merasa tidak mampu melakukan apa-apa untuk kehidupan ini? Dalam hal ini Imam Suprayogo menjelaskan bahwa hal penting yang harus diyakini bahwa persoalan yang ada di sekitar kita terlalu besar, adalah betul. Tetapi, perasaan bahwa kita terlalu kecil adalah awal dari kegagalan kita. ${ }^{21}$

Membangun sains dengan paradigm agama sebagaiman dijelaskan sebelumnya akan menghapus dikotomi keilmuan yang melekat selama ini. Agama dan sains tidak ada pertentangan. Masalahnya adalah ketika sains itu akan diaplikasikan, maka kita akan berfikir tetang norma dan nilai yang akan dikembangkan. Missal, teknologi nuklir itu tidak ada pertentangan Islam. Namun, ketika akan diaplikasikan, maka akan timbul perrtanyaan untuk apa teknologi nuklir itu? Jika untuk berperang, membunuh dan menghancurkan orang lain, tentu saja dalam Islam hal ini dilarang karena bertentangan dengan ajaran Islam. Sebaliknya, apabila tegnologi nuklir itu untuk kemaslahatan seperti pembangkit listrik tenaga nuklir, maka akan menjadi amal shaleh. ${ }^{22}$ Inilah yang kemudian meenunjukkan Islam sebagai rahmatan lil 'alamin.

\footnotetext{
${ }^{19}$ Ibid. 85

${ }^{20}$ Imam Suprayogo, Pendidikan Berparadigma AL Qur'an; Pergulatan membangun Tradisi dan Aksi Pendidikan Islam (Malang: UIN Maliki press, 2004) hlm. 109

${ }^{21}$ Ibid.

${ }^{22}$ Bahrul Hayat \& Mohammad Ali, Khazanah dan Praksis PEndidikan Islam di Indonesia (Pustaka Cendekia Utama, 2012) Hlm. 30
}

Kariman, Volume 07, Nomor 01, Juni 2019| 55 
Kutsiyyah

\section{Kesimpulan}

Ulasan-ulasan singkat dalam tulisan ini hanyalah sebagian kecil dari sekian banyak persoalan yang ada dalam pendidikan Islam dalam mencapai kemajuannya. Namun, dengan perubahan status STAIN/IAIN menjadi UIN memberikan angin segar bagi tumbuhnya pendidikan Islam yang utuh, holistik, integratif dan responsive dengan era modern ini.

Dikotomi ilmu yang ada sejak dulu yang menyebabkan mandegnya keilmuan Islam akan teratasi dengan konsep integrasi keilmuan yang ditawarkan oleh masing-masing UIN. Seperti "pohon ilmu" yang ada di UIN Maulana Malik Ibrahim Malang, "Jaring laba-laba" yang ada di UIN Sunan Kalijaga Yogyakarta atau prinsip integrasi ilmu sebagaimana yang diterapkan dalam pengembangan akademik di UIN Syarif Hidayatullah Jakarta.

Selain itu, perpaduan sistem pendidikan pesantren (asrama) dengan kampus akan memberi banyak manfaat dalam transformasi dan internalisasi nilainilai serta keilmuan Islam kepada mahasiswa. Maka perlu penulis kutip kembali pendapat Albert Einstein, yang mengatakan bahwa "Religion without science is blind: science without religion is lame". Tanpa sains, agama menjadi buta, dan tanpa agama, sains menjadi lumpuh.

Sebagaimana ditulis Prof. Dr. Azyumardi Azra dalam makalah untuk Public Lecture di ICAS (Jakarta 15 Maret 2013) bahwa capaian-capaian yang telah diraih umat Islam Indonesia dalam seratus tahun belakangan ini memiliki makna penting bagi masa depan bangsa dan negara, dan karena itu harus terus dikembangkan dan ditingkatkan. Beliau memperkirakan bahwa sebagian besar perkembangan ini akan terus berlanjut di dalam abad-abad mendatang. Setidaknya, pertumbuhan dan perkembangan itu menjadi modal berharga untuk menatap masa depan yang lebih baik ketimbang di masa-masa silam. ${ }^{23}$

Lebih lanjut beliau menjelaskan bahwa umat Islam Indonesia mestilah banyak bersyukur atas semua pencapaian itu. Memang masih banyak 'PR' yang harus dikerjakan, tetapi itu seharusnya tidak membuat umat Islam tetap memiliki 'mentalitas terkepung' (under siege mentality) atau 'mentalitas pecundang' (losers' mentality), yang dapat membuat orang mudah mengamuk. Harus ada sikap optimism untuk kebangkitan Islam. Semua sarana sudah tersedia, dan kitalah yang memilih untuk memanfaatkannya atau tidak.

\footnotetext{
${ }^{23}$ Azyumardi Azra, http://icas.ac.id/dinamika-islam-menuju-renaisans-indonesia/, diakses 8 Juni 2014
} 
Adalah hal yang patut disyukuri dengan perubahan-perubahan ke arah yang baik dalam sistem dan konsep pendidikan Islam kita. Dengan rasa syukur, umat dapat terus meningkatkan pencapaiannya menuju renaisans pendidikan Islam Indonesia yang jaya untuk masa-masa selanjutnya.

Maka dengan demikian, melihat perkembangan pemikiran Islam dan kelembagaan yang mulai terbuka dengan kemajuan dunia modern saat ini, apabila terus dipertahankan dan ditingkatkan apa yang telah direncanakan dan dikonsepkan dalam UIN, maka di masa yang akan datang besar kemungkinan akan banyak bermunculan ulama yang intelek atau intelek yang ulama sebagaimana diinginkan Prof. Imam Suprayogo.

\section{DAFTAR PUSTAKA}

Abdullah, M. Amin. 2010. Islamic Studies di Pergruruan Tinggi; pendekatan Integratifinterkonektif. Yogyakarta: Pustaka Pelajar.

Abdullah, M. Amin. 2008. Pendidikan dan Upaya Mencerdaskan Bangsa; KEbijakan Pendidikan Islam di Indonesia Dari Dakwah ke Akademik. Jakarta: IIEP.

Ali, Bahrul Hayat \& Mohammad. 2012. Khazanah dan Praksis PEndidikan Islam di Indonesia. Pustaka Cendekia Utama.

Barizi, Ahmad. 2011. Pendidikan Intgratif; Akar Tradisi dan Integrasi Pendidikan Islam. Malang: UIN Maliki Press.

Fadjar, A. Malik. 2009. Pergumulan Pemikiran Pendidikan Tinggi Islam. Malang: UMMPress.

Maunah, Binti. 2009. Tradisi Intelektual Santri; Dalam Tantangan dan Hambatan Pendidikan Pesantren di Masa Depan. Yogyakarta: Teras.

Praja, Juhaya S. 2002. Filsafat dan Metodologi Ilmu dalam Islam. Jakarta: Teraju.

Saridjo, Marwan. 2011. Pendidikan Islam Dari Masa Ke Masa; Tinjauan Kebijakan Publik Terhadap Pendidikan Islam di Indonesia. Bogor: Yayasan Ngali dan al Manar Press. 
Kutsiyyah

Suprayogo, Imam. 2004. Pendidikan Berparadigma Al Qur'an; Pergulatan Membangun Tradisi dan Aksi Pendidikan Islalm. Malang: UIN Malliki Press.

Zainuddin, M. 2008. Paradigma Pendidikan Terpadu, Menyiapkan Generasi Ulul Albab. Malang: UIN-Maliki Press.

Sumber internet:

Abudin Nata, Pengembangan Akademik di UIN Syarif Hidayatullah Jakarta http://fdi.uinjkt.ac.id/ diakses 28 Juli 2014

Azyumardi Azra, http://icas.ac.id/dinamika-islam-menuju-renaisans-indonesia, diakses 8 Mei 2014.

http://academia.edu/, diakses 8 Mei 2014.

http://uin-suka.ac.id http://muslimlife.com/content/read/764/uin-sunan-kalijaga, diakses 28 Juni 2014 